\title{
RECOGNITION OF THE HYPERODAPEDON ASSEMBLAGE ZONE (LATE TRIASSIC) IN A RELICTUAL OCCURRENCE OVER THE SUL-RIO-GRANDENSE SHIELD
}

\author{
BRUNO LUDOVICO DIHL HORN \\ Superintendência Regional de Recife, CPRM/Serviço Geológico do Brasil, Av. Sul, 2291, Recife, PE, Brazil. \\ brunoldhorn@gmail.com \\ CESAR LEANDRO SCHULTZ \\ Instituto de Geociências, UFRGS, Av. Bento Gonçalves, 9500, Porto Alegre, RS, Brazil. \\ cesar.schultz@ufrgs.br \\ ANA EMÍLIA QUEZADO DE FIGUEIREDO \\ Coleção de História Natural, UFPI, Campus Amílcar Ferreira Sobral, BR 343, km 3,5, Floriano, PI, Brazil. \\ aquezado@yahoo.com.br \\ FILIPE ARMANDO MOTTA \\ Programa de Pós-Graduação em Geociências, UFRGS, Av. Bento Gonçalves, 9500, Porto Alegre, RS, Brazil. \\ filipe.motta00@gmail.com
}

\begin{abstract}
A group of isolated occurrences of sedimentary rocks located over the Sul-Rio-Grandense Shield, first described as a temporally intermediate unit between the upper deposits of Camaquã Basin and the lower deposits of Paraná Basin was named Caneleiras Formation, with an inferred Devonian age. Later, the discovery of vertebrate fossils (mainly rhynchosaurs) allowed the stratigraphical assignment of these rocks to the Triassic, correlated to the Santa Maria Formation. However, none of the fossils were complete enough to allow a precise taxonomic assignment, hampering more detailed biostratigraphic correlations. This work reports a new rhynchosaur specimen from an outcrop located at Campinas River, near Santana da Boa Vista, Rio Grande do Sul, Brazil. The presence of one maxillary groove allows assigning the material to the genus Hyperodapedon, index fossil of the Hyperodapedon AZ, which corresponds to the base of the Candelária Sequence, Santa Maria Supersequence. This occurrence shows that, at least on Upper Triassic, the depositional area of the Santa Maria Sequence extended southward of the actual outcrop belt, covering portions of the Shield.
\end{abstract}

Key words: Triassic, Sul-Rio-Grandense Shield, Hyperodapedon, Candelária Sequence.

RESUMO - Um conjunto de ocorrências isoladas de rochas sedimentares, situadas em meio ao Escudo Sul-Rio-Grandense, foi primeiramente descrito como sendo uma unidade temporalmente intermediária entre os depósitos de topo da Bacia do Camaquã (Siluriano) e o pacote basal da Bacia do Paraná (Carbonífero), a qual foi denominada Formação Caneleiras, com idade Devoniana. Posteriormente, a descoberta de fósseis de vertebrados possibilitou o posicionamento estratigráfico de uma parte daqueles sedimentos no Neotriássico, correspondendo à Formação Santa Maria. Entretanto, nenhum dos fósseis encontrados no local permitia uma definição taxonômica ou bioestratigráfica mais precisa. Neste trabalho, foi estudado um esqueleto parcial de rincossauro, proveniente do mesmo afloramento onde foram encontrados os fósseis anteriores, situado no Arroio Campinas, em Santana da Boa Vista, coletado em 1974 e não estudado desde então. A presença de um único sulco entre as fileiras dentárias do maxilar permitiu atribuir o material Hyperodapedon, justamente o fóssil-índice da Biozona de Hyperodapedon, que ocorre na base da Sequencia Candelária da Supersequencia Santa Maria, no pacote triássico que aflora ao norte do Escudo. Esta ocorrência evidencia que, pelo menos no início do Neotriássico, a área deposicional da Supersequencia Santa Maria estendia-se mais ao sul da atual faixa de afloramentos, cobrindo uma boa parte do Escudo.

Palavras-chave: Triássico, Escudo Sul-Rio-Grandense, Hyperodapedon, Sequência Candelária. 


\section{INTRODUCTION}

Discontinuous sedimentary deposits that crop out over the Sul- Rio-Grandense Shield (SRS), near Encruzilhada do Sul, Santana da Boa Vista, and Canguçu municipalities, were first considered as a distinct lithostratigraphic unit (Caneleiras Formation, Tessari \& Picada, 1966). This unit was initially considered of Devonian age, but vertebrate fossils discoveries implied a Triassic age (Menegat \& Scherer, 1993) for at least part of the occurrences, suggesting the correlation of the entire package to stratigraphic units of the Paraná Basin occurring right north of the Shield.

Following that interpretation, Ketzer (1997) recognized layers of the "Caneleiras Formation" corresponding to parts of the Gondwanic second order Sequences I, II and III of Milani (1997). In a lithostratigraphic context, it included portions of the Itararé, Rio Bonito, Palermo and Sanga do Cabral formations (Gondwana I Sequence; Permian-Early Triassic), Santa Maria Formation (Gondwana II Sequence; Middle-Late Triassic), and the volcanic Serra Geral Formation (Gondwana III Sequence; Late Jurassic-Early Cretaceous) (Figure 1). Such correlation indicated that almost part the gondwanic sedimentation of the Paraná Basin covered the area now uplifted where outcrops the Sul-Rio-Grandense Shield.

Later, Zerfass et al. $(2003 ; 2004)$ divided the Triassic Gondwana II sequence of Milani (1997) into three third order sequences (Santa Maria I, II and III), the first two including four tetrapod-based Assemblage Zones. Recently Horn et al. (2014) recognized a fourth third order sequence between Santa Maria I and II sequences, named Santa Cruz Sequence, which included the Santacruzodon Assemblage Zone (AZ). In the same paper, Sequences I and II were respectively renamed Pinheiros-Chiniquá (including the Dinodontosaurus AZ) and Candelária (encompassing the
Hyperodapedon and Riograndia AZs) sequences. However, in none of these previous papers the fossiliferous Triassic outcrops over the shield were analyzed under this allo/ biostratigraphic framework.

In this paper, we report new fossil materials from one of the Triassic outcrops that occur over the Shield, near Santana da Boa Vista, identified as a Hyperodapedontinae rhynchosaur (cf. Hyperodapedon) and a traversodontid cynodont. This allows the biostratigraphic correlation of this occurrence to the Hyperodapedon AZ, at the lower part of the allostratigraphic Candelária Sequence of Horn et al. (2014).

\section{GEOLOGICAL SETTING}

Volcano-sedimentary gondwanic relicts above the SRS crop out in various areas, but the more extensive exposures and thicker deposits occur in the vicinity of Santana da Boa Vista, Encruzilhada do Sul, and Amaral Ferrador cities. These were preserved inside grabens generated by reactivation of some regional faults of mainly NE-SW direction. The studied outcrop (UTM 309375m E, 6582617m S) is located in the Moirão River graben, at the west margin of Campinas River (Figure 2).

The exposed rocks include a succession of coarse sometimes conglomeratic - sandstones with trough cross bedded stratification that grade to siltstones with vertebrate fossils and very fine massive sandstones (Figure 3). The sandstones were interpreted as deposited by fluvial channels and the mudstones as floodplain deposits, characterizing a high sinuosity fluvial system. It does not correspond perfectly to the sedimentary facies of the Candelária Sequence as described by Zerfass et al. (2003). According to those authors, rocks of the Sequence II (Candelária Sequence) correspond to medium to fine-grained, cross-bedded sandstones and mudstones

NW

SE

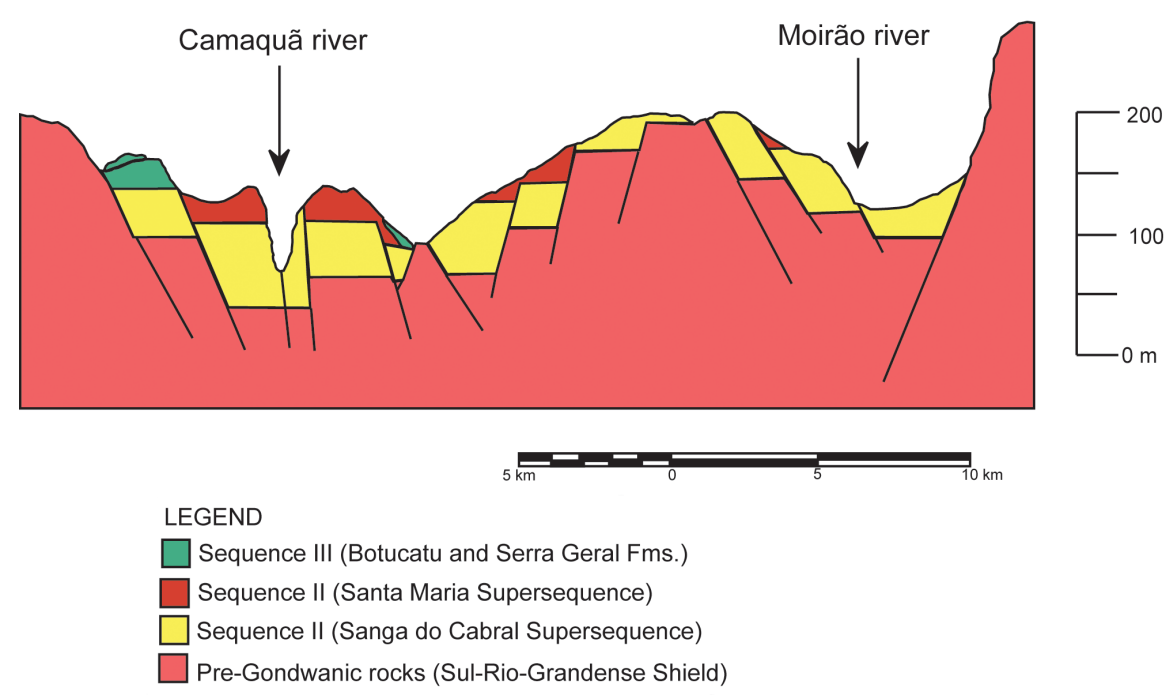

Figure 1. Paraná Basin sequences on Sul-Rio-Grandense Shield, according to Ketzer (1997). Sequences according to Milani (1997) and Zerfass et al. (2003) (modified from Ketzer, 1997). 


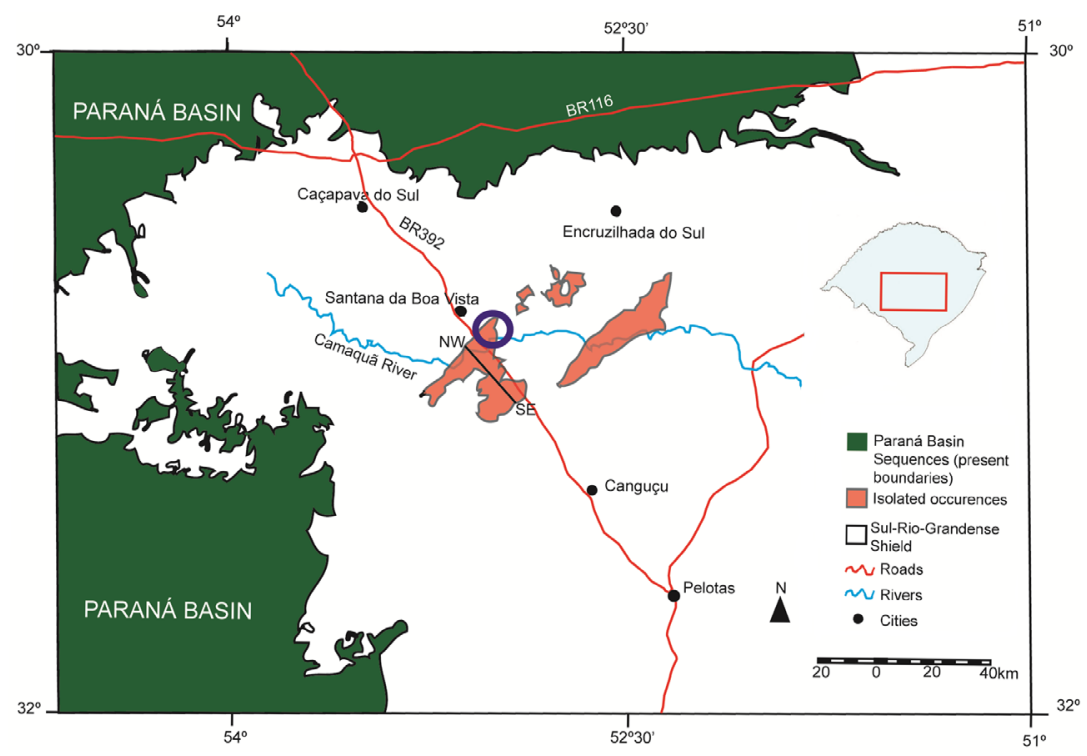

Figure 2. Localization of the studied outcrop (circle) in Rio Grande do Sul State. Modified from Ketzer (1997).

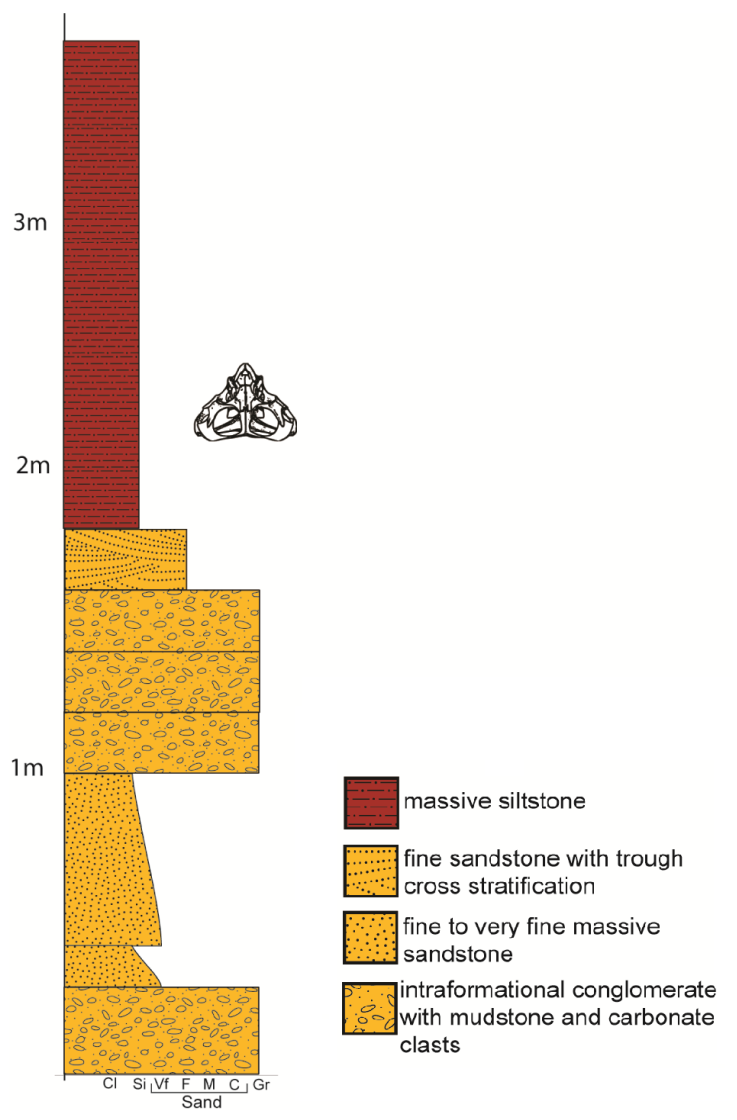

Figure 3. Sedimentary log of the studied outcrop. Rhynchosaur skull indicates the location of the fossil on the outcrop.

lenses at the base, gradating to thick mudstone deposits on the middle part, deposited in a fluvial system with high-sinuosity rivers and floodplains. At the top, the sequence comprises a coarsening-upward succession, including rhythmites with intercalated lenses of fine-grained, cross-bedded, and climbing-rippled sandstones, which represent a lacustrine- deltaic depositional system. The coarser sedimentation found over the shield suggest a depositional context more proximal than typical for the basin.

\section{FOSSIL MATERIAL}

At the studied site, some non-diagnostic rhynchosaur specimens have been previously collected, including femora and ungueal phalanges (Faccini et al., 1990). The new material reported here, UFRGS-PV1248-T, includes six vertebrae (one sacral and five dorsals), interclavicle, some rib fragments, right femur and humerus, a fragment of the right pterygoid, and left pterygoid articulated with the palatine and maxillar (Figure 4).

The maxilla has the typical Hyperodapedontinae pattern, with multiple tooth rows divided longitudinally by one or two grooves (Benton, 1983; Langer \& Schultz, 2000). In the studied material, the presence of a single groove allows its referral to cf. Hyperodapedon (Figure 5).

The maxilla is $154 \mathrm{~mm}$ long, which corresponds to a skull about $280 \mathrm{~mm}$ long. The cranium length estimative is based on comparison with other specimens (Table 1) deposited at UFRGS (Vertebrate Palaeontology collection at Instituto de Geociências, Universidade Federal do Rio Grande do Sul, Porto Alegre, Brazil). The other UFRGS specimens range between 150-240 $\mathrm{mm}$ in length, so this is the largest specimen of this taxon in the whole collection. Associated to the rhynchosaur bones, there is also a fragmentary traversodontid left maxillar without teeth, UFRGS-PV1264-T, probably related to Exaeretodon (Cabrera, 1943) taking into account the characteristic "L-shape" of the empty alveoli. Exaeretodon is also a common taxon present in the Hyperodapedon AZ (Figure 6). Aside from the Brazilian Triassic, the association Hyperodapedon/Exaeretodon also occurs in Late Triassic rocks of Argentina (Ischigualasto Formation) and India (Maleri Formation). 

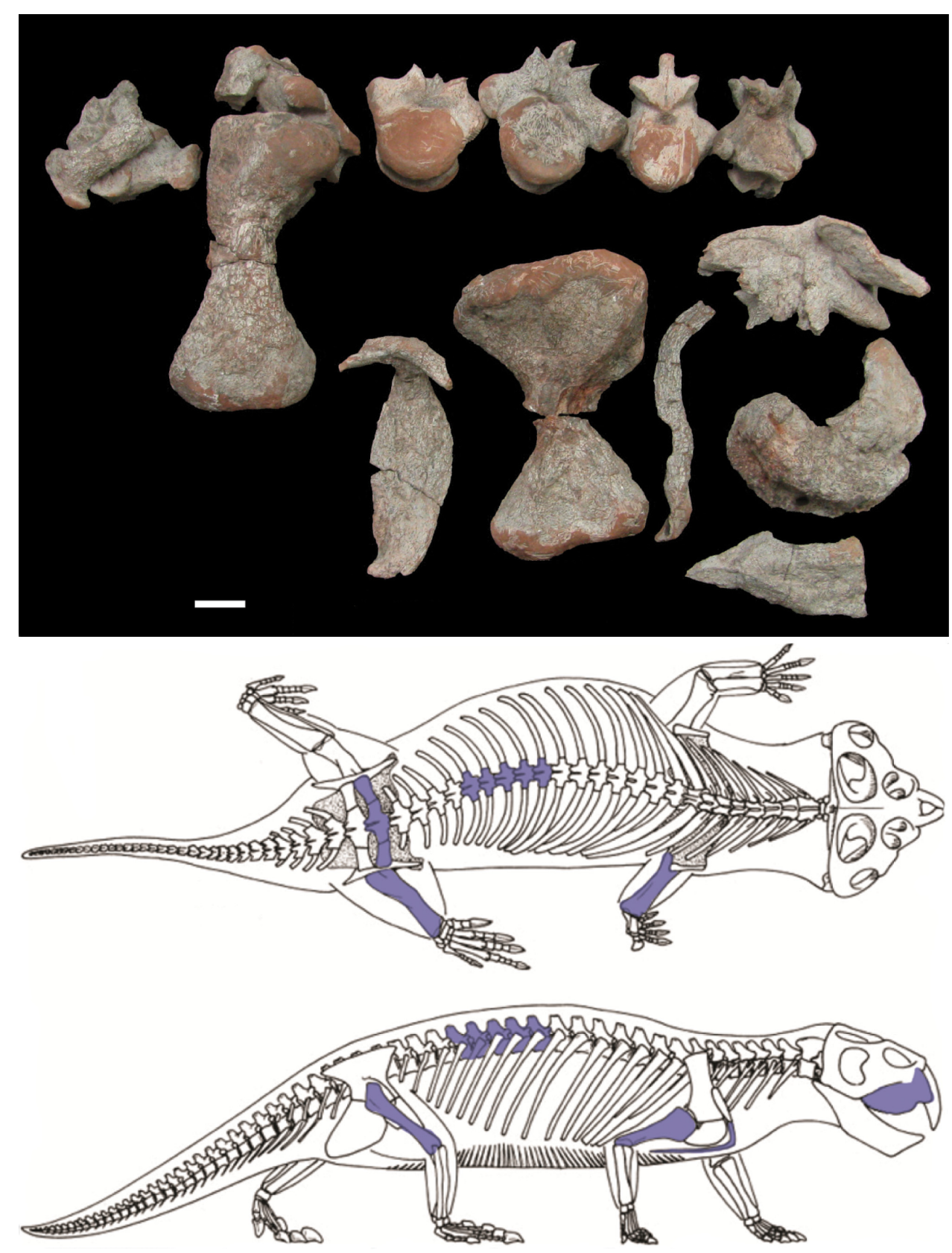

Figure 4. Studied material fossils (UFRGS-PV 1248-T). Top, photographs of the cranial and postcranial material. Below, Rhynchosaur schematic drawing in lateral and dorsal views showing the studied material articulated. Scale bar: $\operatorname{Top}=5 \mathrm{~cm}$. Below $=$ out of scale.

\section{DISCUSSION}

The rhynchosaur Hyperodapedon and the cynodont Exaeretodon characterize the Hyperodapedon AZ (Carnian), as defined for the basal layers of the Candelária Sequence of the Paraná Basin. Indeed, the reported occurrence indicates that the Candelária Sequence covered - even if partially - the Sul-Rio-Grandense Shield in the early Late Triassic. Zerfass et al. (2003) states that the Triassic rocks of Santa Maria Sequence, which occurs only in Rio Grande do Sul State, were deposited in a tectonic context distinct of Paraná basin, as transtensional rifts over the older rocks (including the SRS) that were active during the Triassic. On the other hand, Ketzer (1997) stated that the isolated occurrences of sedimentary rocks over the shield were preserved by tectonic events, posterior to their deposition in faults or shear zones.

Borba et al. (2002) identified significant uplift and seismic activity from Late Permian to Middle Triassic. These could have caused the graben formation and its filling with Triassic deposits. It is worth noting that sediments deposited in these grabens, at least those correlated to the Candelária Sequence, are far coarser than those deposited in the Paraná Basin (Figure 7). This reflects the proximity with the source area for Santa Maria Supersequence, which is suggested to be the Sul-Rio-Grandense Shield itself (Zerfass, 1998). 

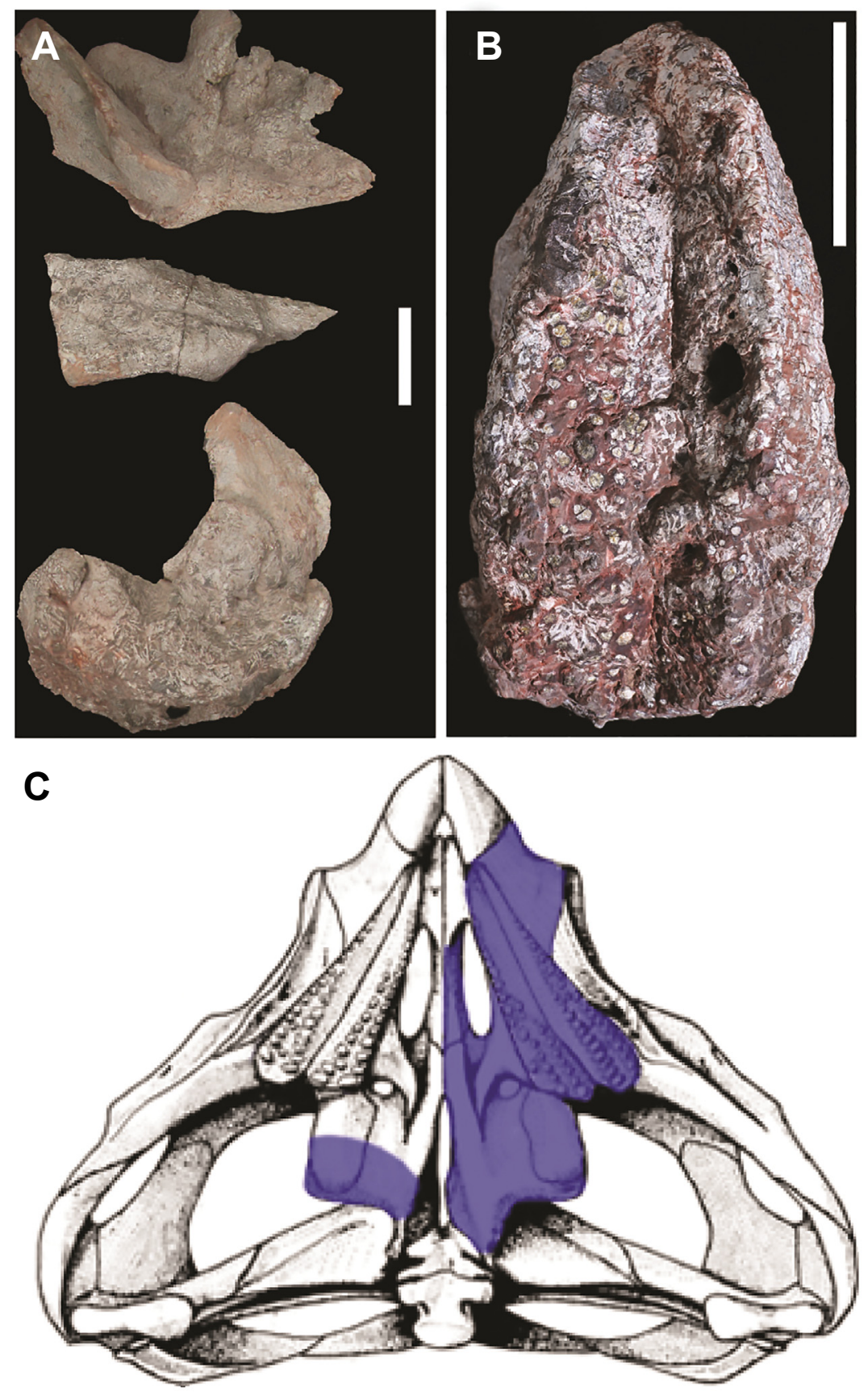

Figure 5. Cranial material (UFRGS-PV 1248-T). A, from top to bottom: right pterygoid in ventral view; left pterygoid articulated with palatine in ventral view; right maxilla in lateral view; $\mathbf{B}$, maxilla in ventral view showing one groove; $\mathbf{C}$, schematic drawing of a rhynchosaur skull in ventral view, showing the presumed position of the studied materials. Scale bars: $A, B=5 \mathrm{~cm} ; C=$ out of scale.

Table 1. Maxillary and cranial lengths $(\mathrm{mm})$ of some rhynchosaur specimens in the UFRGS collection used to estimate the cranial length of UFRGS-PV 1248-T.

\begin{tabular}{lcc}
\hline & Maxilla & Cranium \\
\hline PV0313T & 132 & 240 \\
PV0408T & 120 & 235 \\
PV0199T & 101 & 150 \\
PV1248T & 154 & 280 \\
\hline
\end{tabular}

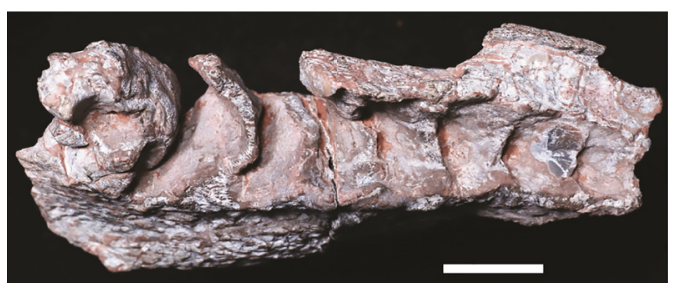

Figure 6. UFRGS-PV 1264-T, right dentary in occusal view. The shape of the empty alveoli clearly identifies it as a traversodontid, most likely Exaeretodon sp. Scale bar $=1 \mathrm{~cm}$. 

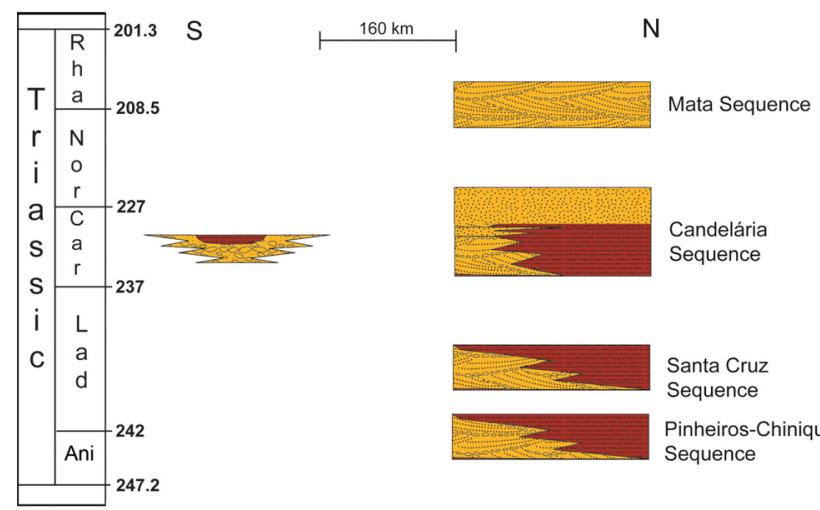

Figure 7. Correlation between the Triassic rock of the Candelária Sequence over the Sul-Rio-Grandense Shield (S, South) and inside the actual limits of Paraná Basin (N, North). Abbreviations: Ani, Anisian; Lad, Ladinian; Car, Carnian; Nor, Norian; Rha, Rhaetian. Ages from Gradstein et al. (2012).

\section{CONCLUSIONS}

New rynchosaur specimens found near Santana da Boa Vista allowed the identification of the genus Hyperodapedon and, in consequence, the correlation of the bearing rocks to the Hyperodapedon AZ and the extension of the Triassic deposition of the Santa Maria Supersequence over the SulRio-Grandense Shield, in the Late Triassic. However, the structural and depositional context of the Triassic rocks of Southern Brazil, that occurs only in Rio Grande do Sul State, are still unsatisfactorily known. The age of the grabens are uncertain, as are their possible influence on the deposition of these rocks. Indeed, more tectono-sedimentary studies are necessary to explain this depositional history of the Gondwana II Sequence and its relationship with the SRS.

\section{REFERENCES}

Benton, M.J. 1983. The Triassic Reptile Hyperodapedon from Elgin: Functional Morphology and Relationships. Philosophical Transactions of Royal Society, 302:605-718. doi:10.1098/ rstb.1983.0079

Borba, A.W.; Vignol-Lelarge, M.L.M. \& Mizuzaki, A.M.P. 2002. Uplift and denudation of the Caçapava do Sul granitoids (southern Brazil) during Late Paleozoic and Mesozoic: constraints from apatite fission-track data. Journal of South American Earth Sciences, 15:683-692. doi:10.1016/S0895-9811(02)00086-X

Cabrera, A. 1943. El primer hallazgo de terápsidos en la Argentina. Notas del Museo de La Plata, 8:317-331.

Faccini, U.F.; Schultz, C.L.; Figueiredo, C.E.; Sangineto, L.R. \& Soares, S.C., 1990. et al. 1990. Sobre a ocorrência de vertebrados fósseis triássicos na região de Santana da Boa Vista (RS). Ciência e Natura, 12:103-104.
Gradstein, F.; Ogg, J.; Schmitz, M. \& Ogg, G. 2012. Geological Time Scale 2012. Elsevier, 1176 p. doi:10.1016/B978-0-44459425-9.01001-5

Horn, B.L.D.; Melo, T.P.; Schultz, C.L.; Philipp, R.P.; Kloss, H.P. \& Goldberg, K. 2014. A new third-order sequence stratigraphic framework applied to the Triassic of the Paraná Basin, Rio Grande do Sul, Brazil, based on structural, stratigraphic and paleontological data. Journal of South American Earth Sciences, 55:123-132. doi:10.1016/j.jsames.2014.07.007

Ketzer, J.M.M. 1997. Cronoestratigrafia das unidades Gonduânicas preservadas sobre o Escudo-sul-rio-grandense (Formação Caneleiras). Programa de Pós-Graduação em Geociências, Universidade Federal do Rio Grande do Sul, Dissertação de Mestrado, $215 \mathrm{p}$.

Milani, E.J. 1997. Evolução tectono-estratigráfica da Bacia do Paraná e seu relacionamento com a geodinâmica fanerozóica do Gondwana sul-ocidental. Programa de Pós-Graduação em Geociências, Universidade Federal do Rio Grande do Sul, Tese de Doutorado, $255 \mathrm{p}$.

Langer, M.C. \& Schultz C.L.2000. A new species of the Late Triassic rhynchosaur Hyperodapedon from the Santa Maria Formation of south Brazil. Palaeontology 43:633-652. doi:10.1111/14754983.00143

Menegat, R. \& Scherer, C.M.S. 1993. Formação Caneleiras (RS) Devoniana ou Permo-Triássica? Critérios para o enquadramento estratigráfico das bacias isoladas sobre o Escudo Sul-RioGrandense. In: SIMPÓSIO SOBRE CRONOESTRATIGRAFIA DA BACIA DO PARANÁ, 1, 1993, Rio Claro. Resumos expandidos, Rio Claro, UNESP, p. 90-93.

Soares, M.B.; Schultz, C.L. \& Horn, B.L.D. 2011. New information on Riograndia guaibensis Bonaparte, Ferigolo and Ribeiro, 2001(Eucynodontia, Tritheledontidae) from the Late Triassic of southern Brazil: anatomical and biostratigraphic implications. Annals of the Brazilian Academy of Sciences 83:329-354. doi:10.1590/s0001-37652011000100021

Tessari, R.I. \& Picada, R.S.1966. Geologia da Quadrícula de Encruzilhada do Sul, RS. Rio de Janeiro, Departamento Nacional de Produção Mineral, Divisão de Geologia e Mineralogia, 147 p. (Boletim 124).

Zerfass, H., 1998. Estratigrafia da sedimentação Meso e Neotriássica no Município de São Pedro do Sul, RS: faciologia, análise de proveniencia e história diagenética. Graduação em Geologia, Universidade do Vale do Rio dos Sinos, Trabalho de Conclusão de Curso, 177 p.

Zerfass, H.; Chemale Jr, F.; Schultz, C.L. \& Lavina, E.L. 2004. Tectonics and sedimentation in South America during Triassic. Sedimentary Geology, 166:265-292. doi:10.1016/j. sedgeo.2003.12.008

Zerfass, H.; Lavina, E.L.; Schultz, C.L.; Garcia, A.J.V.; Faccini, U.F. \& Chemale Jr, F. 2003. Sequence stratigraphy of continental Triassic strata of Southernmost Brazil: a contribution to Southwestern Gondwana palaeogeography and palaeoclimate. Sedimentary Geology, 161:85-105. doi:10.1016/S0037-0738(02)00397-4

Received in September, 2014; accepted in March, 2015. 